\title{
THE ROLE OF THE INDIGENOUS KNOWLEDGE SYSTEM OF THE COMMUNITY DAYAK IN WATER MANAGEMENT KAHAYAN RIVER: REVIEW OF LOCAL WISDOM PERSPECTIVE
}

\author{
R.Sally Marisa Sihombing \\ Social and Political Science Faculty of Palangka Raya University \\ sallymarisa.fisip.upr@gmail.com
}

\begin{abstract}
Watershed Management (DAS) is expected in the future to provide a framework towards achieving sustainable development. Watershed management itself is a renewable resource of plants, soil and water in order to provide maximum and sustainable benefits. Watershed management is a human effort in controlling the reciprocal relationship between natural and human resources with all its activities in the watershed. The goal of watershed management is to foster the sustainability and harmony of ecosystems and to increase the utilization of natural resources for humans in a sustainable manner (RLPS, 2002) In relation to watersheds, the Central Kalimantan region is an area whose surface is a river flow. This is evident from the availability of the lanting house as a community residence on the shore of the Kahayan river. There is also the presence of Handil or Saka within the Kahayan river area which is a sluice gate or known as tabat in managing the river, as well as the culture of catching fish which is called Mihing as a tool for Dayak people in fishing.

From the previous research, the dissertation research (Sihombing 2014: 89) states that there is a local culture produced by local Dayak people in managing the river which is an innovation for the community to fulfill their daily lives. (Sihombing, 2016; 223) This is what is called the Indigeneous Knowledge System, which is the knowledge system of the local community which is considered as an originality or originality of the knowledge of the community.

Departing from this thought, the research that has been carried out from the dissertation research derivative then the methodology used is qualitative ethnography with the aim of further exploring and studying the indigenous knowledge system in the Dayak community in managing the river, and this is what makes the concept of indigeneous knowledge system play a role in river management is seen from a review of the perspective of local wisdom that has been ingrained. This paper is also a continuation of the results of research that has also been carried out, which found that there is a correlation or relationship between innovation and knowledge systems of local communities, is a study of Public Administration in examining more broadly the implementation and understanding of social science in formulating policies that lead to fulfillment of community life needs and management.
\end{abstract}

Keywords: Role, Dayak Community, Indigenous knowledge system, Local system and River basin management.

\section{INTRODUCTION}

Communities around the peat area are actors in managing and maintaining peatlands. However, what is found in the field is the lack of knowledge received by the community in overcoming difficulties in the peat area. This knowledge is also certainly rather difficult to implement in today's modern era. But in practice the community certainly cannot walk alone without assistance from the government as an agent 
that facilitates and directs the community in overcoming the difficulties surrounding the peat. Especially related to the social and economic development of the community. But the government forgets when it wants to implement the program, so the government does not make an introduction to the community, the habits of the community, principles, beliefs and knowledge possessed by the community in its understanding of the peat environment. And as stakeholders and decision makers, the government certainly has the capacity to manage peat, both technically and socially. This is clearly stated in Presidential Instruction no. 02 of 2007 dated March 16, 2007 which made four main programs namely conservation, agricultural revitalization, community empowerment and coordination of program evaluation. (Masterplan EMRP, 2008: 4)

Reviewing peatland management, the problems that arise in peatland management are the lack of mutual understanding in anticipating environmental changes that occur. Only some programs are actively implemented in carrying out field work and interact directly with the community, as a result there is no mutual understanding or values built in government or public organizations that are directly related to peat management, so how to deal with environmental changes, namely the peat swamp water environment and the potential of the community in overcoming the problem of peat is never complete. (Sihombing, 2016: 5)

The second problem that arises is the low trust of public organizations or other parties in practicing peat management itself. The absence of understanding in adhering to the belief whether the peat swamp river is an ecosystem that requires a management system that is in accordance with its characteristics and functions. Variations in characteristics and functions require variations in efforts to manage the government or public organizations entrusted with the task of managing peatlands at this time not fully practicing good and targeted river management efforts. The management media referred to by researchers take the example is the development of infrastructure as a form of management effort, because the goal of developing the river management infrastructure for peat swamp is to maintain the quality of river water so that the river environment is restored to reduce disaster risk and its consequences. The existing infrastructure development also did not occur in Central Kalimantan, especially infrastructure from upstream to downstream in accordance with the designation of water. (Sihombing, 2016: 6)

Third, related to the policies of the Regional Government in producing the policy of river water resources in peat swamps, in the implementation of government policies often ignore the interests of the community and the lack of commitment of the government and the community in preserving the environment around the river body. Public organizations that are directly related to the management of the peat swamp river area, are lacking in human knowledge and the ability to manage and utilize river water resources in Central Kalimantan. As a result the community is not familiar and the resulting policies are not well socialized in managing the Kahayan peat swamp river area. (Central Kalimantan EMRP Consulting Report, 2009)

\section{INDEGENEOUS KNOWOLEDGE SYSTEM (IKS) APPROACH AS A METHOD OF REVIEW OF RAWA RIVER RIVER MANAGEMENT.}

In the writings of Professor L. Jan Slikerveer in his presentation on March 30, 2015 stated that "Indigeneous Knowledge System (IKS) is a special system adopted by the community specifically which includes a system of knowledge, beliefs, and behaviors that develop from generation to generation in a localized way that is a distinctive community that is summarized in a culture and region known as local wisdom of the local community. . "

Indegeneous Knowledge System (IKS) is very important for the implementation of community development. The reason is a system that has an important role for society, especially in making decisions in the community. The journal offered by Weddel et al (2005: 30-51) with the title "Toward 
an Anthropology of Public Policy" related to decision making, this paper seeks to discuss how studies of anthropology have long had a relationship with public policy. Such as institutional issues and power, ethnicity, community identity, politics of a culture, and interaction between decision makers at the government level with decision makers at the community level and interactions between global and local.

Through an understanding of indigenous knowledge systems in understanding anthropology of public policy, Weddel et al (2005) revealed in his writing:

"In the ultimate sense, society itself policy making, the understanding is that society is someone who makes the decision itself". When the community becomes the personal figure who makes the decision, then studying the indigenous knowledge system (IKS) is not just to document various cultural heritages and local wisdom typical of a society, but IKS also has the potential to empower local communities related to the environment they face to create community development which are independently sustainable with knowledge systems passed down from generation to generation.

For the development of IKS, it becomes very important because the system that is formed in the midst of society is to support decision making that is right in the community. For social culture, political politics is an important contribution because the IKS approach is a multidisciplinary science or a good aspect of technical and social with confidence in it is believed to be effective in providing solutions to a number of problems faced today. Further problems can be mapped as follows:

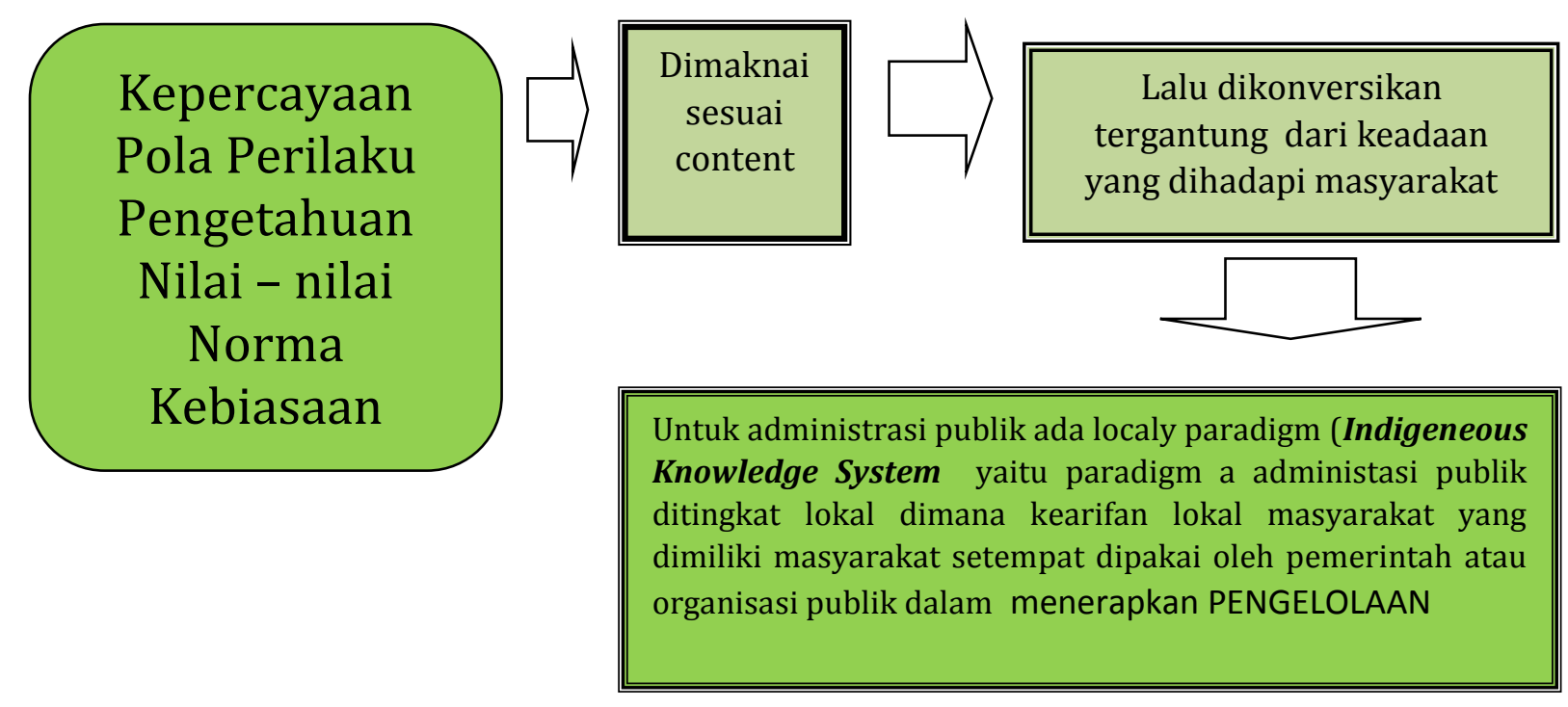

\section{Gambar 1 : Pemetaan Indegeneous knowledge system}

\section{RESULTS AND DISCUSSION}

The Dayak community is a gynecogical society that is a society that has institutions that regulate life together in the context of the environment or place of residence, and people who live together in lineage. The environment of peatland is an area or environment that makes the Dayak community so high in the nature that they occupy.

The results of the study show that there is an understanding of how inseparable the knowledge of society, namely the indegeneous knowledge system and mindset. Like the mindset of the people around the peat swamp river in living and understanding the peat as the area where they live. This is evident from the culture of the Dayak community which reflects that all symbols of the way of life, habits and beliefs are crystallized into works of art. 
Therefore, the maintenance of community culture which contains a local knowledge system is very supportive of the implementation of management. Such as giving meaning to what the Dayak community has, such as the river environment, peat swamps, natural potential, local wisdom, customs, which are worth preserving.

Through IKS, the researcher formulates that there is an effort to balance the culture of the local community with the activities of daily living and its relationship with the government as an Actor in the public servant through Culture Sharing. That is how culture is understood in society, and through culture also the community is able to overcome difficulties and challenges faced in the area where the community lives.

\subsection{Management of river or water areas based on understanding indigenous knowledge to local culture.}

Dayak people who are river communities experience a process of change in addressing water problems. This can be seen from the changes from the past, namely the people who have confidence in the management of the river area, such as the management of the river area through the construction of lanting houses and the management of river areas or water through the construction of a water gate. This phenomenon shows that the Dayak community in the past has such a specific understanding of things related to management.

Even though the community experiences a period of time, the community does not realize that the community has used its ordinary knowledge to overcome its environment. And the problem of the river or water area that meets the area of the river has decreased, that is, the community no longer manages the river area with former cultural traces but tends to allow the passing of the local cultural meaning, such as the Lanting house which has been replaced by a wall house. The house was built on the side of a river or on the edge of a river. Likewise with the construction of the Tabat sluice gate which is no longer recommended in managing the river, especially the river area which is a tributary. As disclosed by Arsenault (2018) states that:

This challenge is exacerbated by the legal system, science, and current policies which exclude perspectives, knowledge and worldview of Indigenous, and choose to give the privilege of western science as the final authority.

The purpose of this statement is that many people now do not realize that understanding indigeneous knowledge is an understanding that can provide solutions or solve problems, and become a force. Indigeneous system knowledge is also a system that is built from public relations to the surrounding natural areas. However, many understand indigenous knowledge is not used as material in policy making, especially in the management of river areas. As a result the findings in the field lead to a decrease in water degradation, the occurrence of river pollution such as chemical mixtures with rivers when local people take or mine gold in the wild areas or usually upstream of the river.

Researchers took the example of the Kahayan river region in Central Kalimantan, from the results of the field, researchers found an attachment between understanding indigenous knowledge with water areas so as to form culture, which is called the culture of living or the culture of river communities.

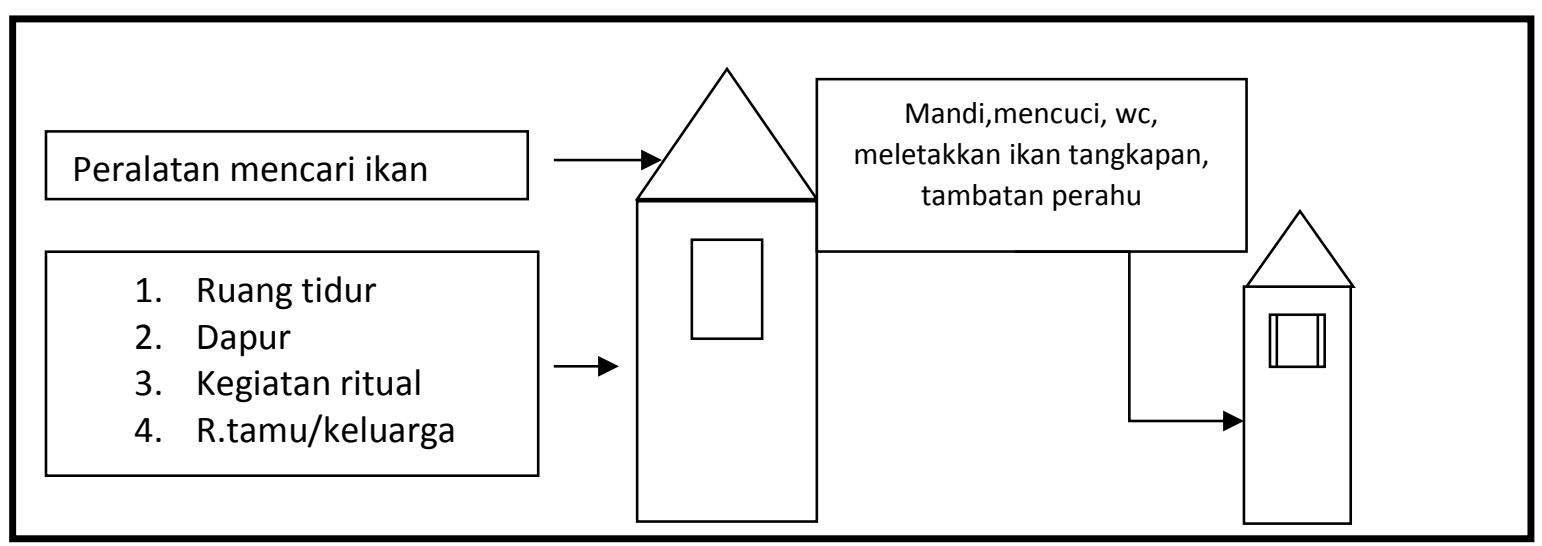




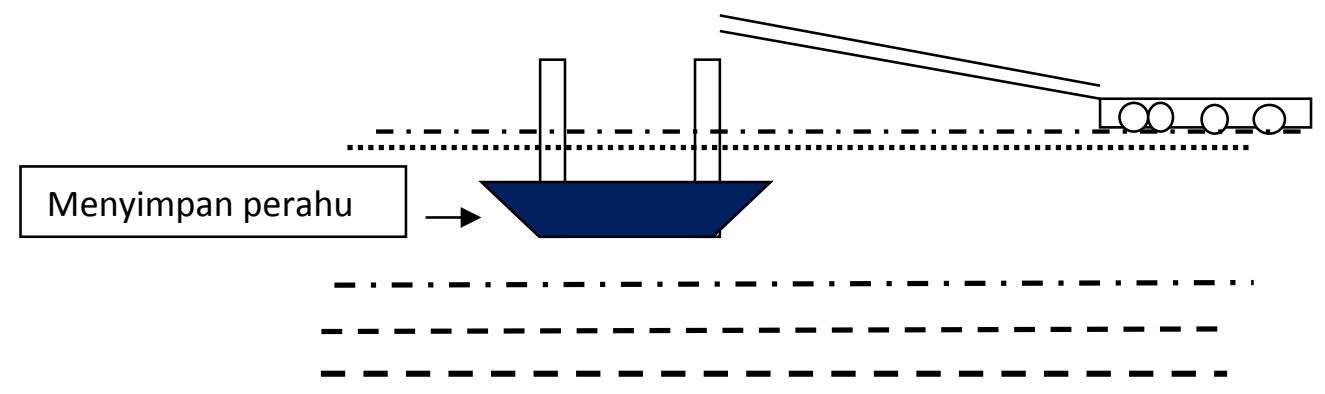

Gambar 2 :

Gambar sungai yang divisualisasikan dalam sketsa yang dipercayai sungai sebagai

Tempat kelangsungan Masyarakat Dayak

This resident culture is reflected in a Lanting Huma as a river community residential house is a house that is supported by many pillars that are plugged into watery or swampy land. The height of the house pole is about 3 meters with a house dimension of about $5 \times 5 \mathrm{~m}$. In front of the house there is a sanding whose pillar is plugged into a runny land. The door of the house contained a staircase that rested on a wooden land like a dock.

This resident culture is built to form a small community that is above the occupancy of the lanting house, and this culture is also a means of knowledge for the Dayak community in solving community problems or needs. The understanding of indigenous knowledge which is believed by the community is also the incarnation of the creator that is contained in the water area. The relationship between the creator and the water area or river is authorized to a traditional figure who is trusted as God's representative. Spiritually, traditional leaders in the community are representatives of God who have connections with spirits in the river and are believed to create a new life that is bringing new water life. It is with this belief that the community respects and respects the river. Through the rituals in it, the river community or Dayak people believe that the spirits in the river are God who protect them from water disasters such as floods and landslides.

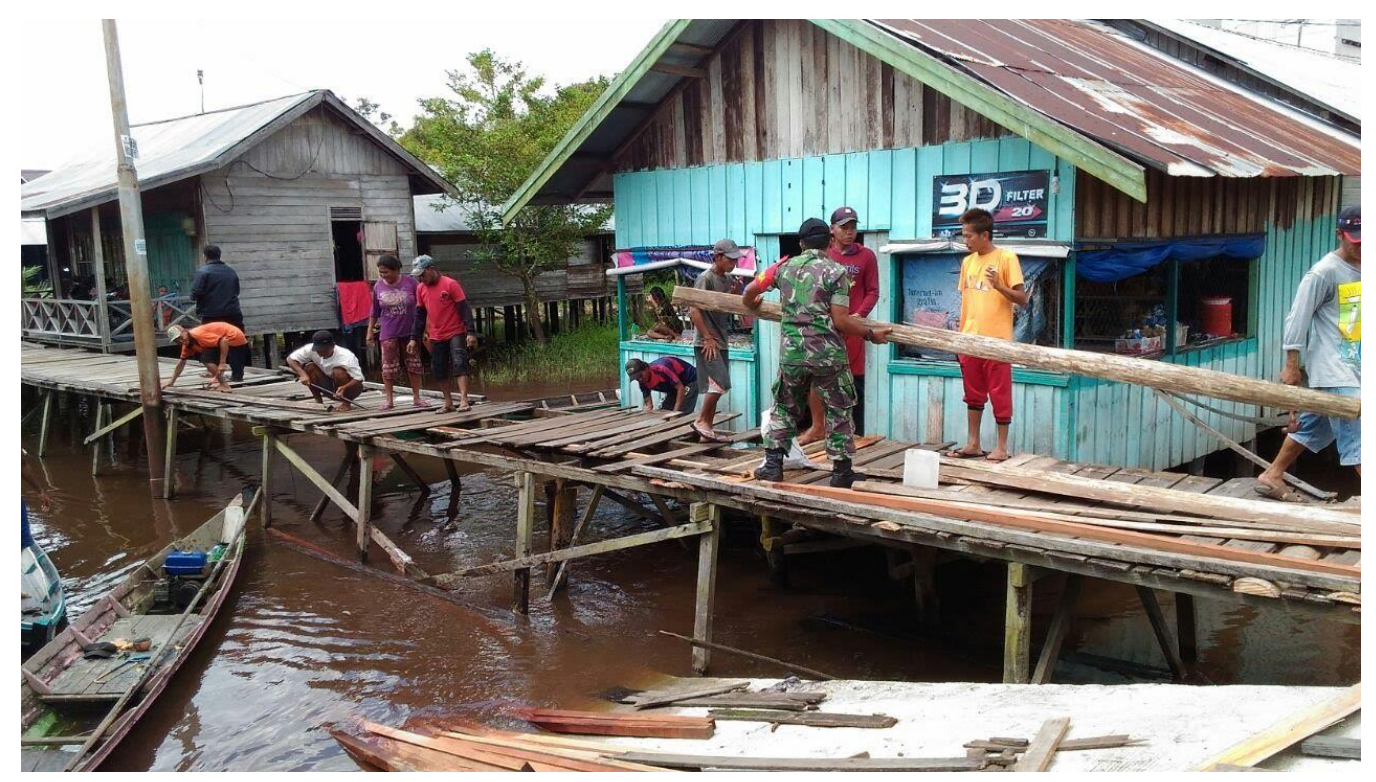

Gambar 3:

Gambar yang diambil peneliti dari salah satu desa yaitu desa Pilang dalam suatu keterikatan hunia atau budaya bermukim yang dibangun masyarakat yang ada diatas sungai 


\subsection{A form of local culture that describes the attachment of community housing on the river. 3.2.1. Symbol Direction of River (Upstream-downstream).}

The Dayak Ngaju ethnic community, which from the beginning was a river community, made upstream and downstream as signposts having a symbolic meaning that was very important for Dayaks. Settlements - Dayak settlements are almost entirely along river banks, so understanding of direction is always associated with river flows. In ancient times, the Dayak Ngaju ethnic community only used east and west directions or referred to the upstream-downstream axis. It is also meant that there is a village or village, when the Dayak community has coexisted with neighboring villages, to designate a Village A or Village B, the community mentions the upstream or downstream direction. This direction indicator is used to indicate the direction of the location of one house to another. The Dayak community is used to mention inland areas, whatever their sub-districts are upstream, and when ordinary people go to the banks of the river it is called downstream. Likewise, the community is accustomed to mentioning a distant place, which is unknown or unclear in its direction, especially a large city or a place that is unfamiliar, as upstream, and to designate a place or a more developed area or urban area called downstream.

3.2.2. The Dayak Rituals in managing the river.

Ethnic Dayak community relations with land, earth, water, rivers, beaches, lakes are very important and everything is revealed in the customary system. Besides involvement and togetherness as creatures that occupy the earth, as illustrated in the creation myth, the Dayak ethnic community also expresses its gratitude to the earth and nature (forests, rivers) so as not to lose the power of growth that results in human damage. Therefore, a treatment or provision is needed which regulates that the balance and harmony of life whether human or natural is maintained.

Efforts that regulate balance and harmony are contained in rituals or ceremonies, because the Dayak ethnic community never dares to intentionally destroy land and forests. Forests, earth, rivers and the whole natural environment are part of life itself. Before taking something from nature, Dayak people always give first. Starting with giving a dish to the owner of the earth, the Dayak community performs rituals that relate to the culture and activities of daily living of the community.

The Dayak ethnic community has a culture namely river culture, which means that people live in harmony with the river or water resources. Here the Dayak Ngaju community adjusts to the natural state of the river. Like a river that flows and people also use the river as a place to live, what is called a living culture. The purpose of the culture of living is that the Dayaks prefer to live in the river with the consideration of being able to access the source of life on the river. And the river is a suitable place to use the river to meet the daily needs of the community.

Ngaju Dayak Ethnic Communities who live in rivers, perform rituals because they relate to the religion they profess. And ritual is an activity that aims as an offering. Rituals are more DOA, where the Dayak ethnic community asks for healing, protection, prosperity, for the god of the cosmos, the god of the river or the God of the water. As stated by the upstream Kahayan river community, which states:

"The Dayaks believe that if a river is inhabited by a god, when there is a sick person in our village, usually families who experience pain do a repellent ceremony (Manyudiri)"

The dependence of the Dayak ethnic community is seen in the rituals that are carried out when people experience something bad like severe illness, death of animals or relatives, which is considered a disaster other than natural disasters such as floods, landslides and drought. As explained by the Community Leader at Kahayan Hulu which stated:

"Barega ritual will be Dayak Ngaju awi feeds sahur iyete kahandak atei oloh Dayak balaku bara Hatalla warmly protects by hong parak sungei: very important ritual for the Ngaju Dayak community, because 346 
ritual is a feeling that describes the contents of society to ask God or God to protect community around the river.

For that from the results in the field, the researchers managed to summarize some forms of rituals held in the river community of the Ngaju Dayak ethnic group, namely:

1. Soaring Ritual is a ritual held by Dayak people by offering offerings to the river, by making a small boat in the middle of which there is a small house, and the boat is given a ballast, which after prayer, the boat is released in the middle of the river, and drowned, accompanied by dance - dances and musical instruments, namely gongs or drums.

2. Ritual Balai is the agreement with the king of crocodiles is to the human side, humans cannot take a bath in the middle. And humans after marriage cannot go down the river. And humans also cannot kill crocodiles, unless the crocodile is guilty. From the crocodile, the crocodile will not bask in the mainland of the riverbank, crocodiles will also not kill humans unless humans have birthmarks on their bodies. (Because for the Dayak community, there is a habit of the mark that is in his body which is usually near the eye, there is a dead vein near the eye, and if the person is marked like that, it will usually die in the river) Furthermore, the crocodile is also not able to enter BUWU (1 meter long rattan commonly used to catch fish and put on the edge of a river) unless the crocodile is guilty of killing humans, the crocodile deserves to enter buwu. Once agreed, Bawi is brought home by Damang. The message of the story is that women who again come back to the river should not be around the river, or newly married women are diverted to go down the river. 2.Lauk Je Dia BatisikSide of Palangka Raya, there is a village called Handak on the edge of the Kahayan River. In the past, people in Hendak Village were attacked by a mob of worms. Worms eat plants in the village. Until finally because this plant has run out, the worms eat humans. Someday there is someone who goes up to the tree that is leaning towards the river, and when the worm wants to eat someone, then something emerges from the river. Lais, baung, pentet (catfish) came out to eat the worm and after that finally the community was saved. Because of the fish that saves people, there is an agreement, the fish that is not scaly should not be eaten by the community.3. Nyai Talaong Ngambun. There are 2 beautiful women who are diligent and meet 2 men who are kaka beradik. The first man was called sangkuak, fell in love with the woman named Nyai Talaong, but Sangkuak's love was rejected by Nyai Talaong. Then Sangkuak in desperation made the vow that his body was more useful to nature and finally the god of heaven cursed Sangkuak. Nyai Talaong finally married Sangkuak's sister, Sangkuang. But Nyai Talaong finally realized that he was not in love with Sangkuang, and Nyai Talaong finally cried overnight, and his tears turned into river water.4 Tambi Uan and Bawin. One Jabiren village, there was a river called TANGININ, and was inhabited by a grandmother who named Tambi Uan with 5 houses on the riverbank. One day at midday there was a big fly approaching Tambi Uan and his two grandchildren while catching fish. Tmbi Uan with his grandson tried to catch a big fly, with rattan on his back. When it happens taking a big fly occurs an environment that changes, namely a dark atmosphere followed by lightning. Tambi Uan and his two grandchildren were cursed to stone, during the afternoon the other grandson of Tambi looked for Tambi Uan and his two grandchildren. When Tambi's grandson found three stones, finally the grandson of Tambi Uan moved away from the river where Tambi Uan was condemned. Cucu Tambi Uan finally lived in a deep forest, next to the Hulu Palabangan river. But far away in the forest, Tambi Uan's grandson experienced threats from the forest thugs. And finally the Tambi Uan grandchildren finally made a ceremonial ritual that received revelations from the sky council to promise that it should not interfere with the generation of the Tambi Uan family, and should not dispose of rice powder that is usually sifted by the community for rice needs and should not throw garbage in the river. into the Dayak region changing the way the Dayak people view the river. Understanding of knowledge and technology for indigenous people is basically influenced by the perspective of the community itself which is very closely related to the culture of the Dayak community. With all its uniqueness, the Dayak community survives in the culture of the river which makes the Dayak community as a river community, but in the 1980s the culture of the river has begun to be taken care of by world civilization, consequently the transfer of legend as knowledge that 
goes orally with examples of actions from parents to generations the next began to falter - with many young people who had to leave the village for a long time due to economic reasons and for the sake of school. The importance of formal schools coupled with the role of mass media and external culture infrastructure has also become an influence on the Dayak community and finally in this context, the traditional culture of indigenous people has become very marginal in managing the river naturally and traditionally. 3.2.6. The Cultural Value of the Dayak Ngaju Community in managing the river. Dayak people basically consider the universe to be composed of the upper realm and the lower realm. The upper realm is controlled by Ranying Hatala sky and is lived as a moonlighting sea, sea babandan diamond (golden sparkling lake, sea lined bond diamond). Whereas the lower realms are nature controlled by JATA (water snakes) and lived as basuhun bulau saramai rabia (golden river flowing wealth). Like the expression of the river coastal community of Petak Bahandang Village (Hulu Sungai Kahayan) which stated that besides being trusted by the ruler of the river is a snake, in this area, the headwaters of the Kahayan river have a ruler who is believed to be a crocodile called KUDUNG TUMBANG MARUHUNG KAKI RADEN, and the river here is a gift from God is guarded by the ruler of the river to fulfill the daily needs of the Dayak community and is believed to be the protector of the community. Because the culture of the Dayak community is a culture that has harmony with the river, the culture carried out by the Dayak community has values that are: Sustainability of natural resources (Sustainability value) The Dayak community is a community that has emotional nature. Nature is believed to be the soul that safeguards the life of the Dayak people in carrying out the routine of life. This means that the Dayak community has a pattern of life that is very dependent on nature in this case is the river. And the river is a nature that needs to be maintained for the survival of the Dayak community, especially in the river. The community has a reason to live on the river coast because the river is an access that is very easy to reach by the community and becomes the center of life for the Dayak people (river community) which is called a place of residence or a place to live. material culture of the Dayak community. The material culture of the Dayak community is a product of the Dayak community known as Rumah Lanting (a house built specifically on the river). The meaning of the culture of the Lanting House was originally as a place to live the Dayak people who were born as river communities, and here created the meaning of mutual relations between the community and the river. When the community maintains the river, a healthy river can be consumed by the community. As in the picture above, that the Dayak community conforms to the river, not the river that adapts to society. This is where people function their culture as a value of sustainability from the existence of reciprocal relations between the community and the river and river with the community. As stated by one of the Customary Leaders of Palangka Raya, who stated that the life patterns of the Dayak people were very influential on the survival of the community, so this had an effect on the material culture created by living on the river like the building of the Lanting house. Dayak people who contain river sustainability values, namely settlements that grow on the edge of the water usually start from the edge of the water. Soejono in (Sanggalang, 2013: 33) humans know settlements estimated since the mesolithic period. Communities live in groups where natural conditions can fulfill life such as caves that are close to food sources or open places such as rivers, lakes and beaches (waterfront). The river is the beginning of the opening of relations with other communities where a community lives. Most settlements start from areas around water, either rivers, lakes or sea, where watery areas are chosen so that people can be assured of their clean water supply. The river is believed by the Dayak community to be a transportation infrastructure, a means of meeting other people, and exchanging knowledge. Understanding the cultural value created by the people who live along the river produces family values, religious values and mutual cooperation. Dayak people who live on the banks of the river, will gradually develop through the process of marriage, so it is not surprising if one of the riverside communities gather together from the same ancestors. As expressed by the customary figures of Central Kalimantan in their statement stating that the Ngaju Dayak community on the edge of the river is called SITEN, and a known culture is BETANG culture. This culture was built 
by the riverside community for the purpose of mutual cooperation, namely a kind of FORM to protect people or families that are set up or lanting to fend off ASANG (war) attacks. The fort is carried out 3 $4 \mathrm{~km}$ long. An important value also for the Dayak community is spiritual value. The river has an important role because it is the upper natural life and the lower realm in the Dayak tribal conception which is a harmonious blend and sacred cosmos, so that water (river) is very important in spiritual life for the Dayak people and makes water or river as a dominant space in establishment of settlement units. The closeness of the Dayak community to the river is manifested in to the belief of Dayaks who consider that water is the source of life. Therefore the river is manifested in various forms of traditional ceremonies or beliefs with the purpose associated with the river. Based on the Dayak customary concept, the settlement of the Dayak community on the banks of the river is always associated with the belief that the upstream river has good meaning while the downstream means bad. As a result, the direction of the Lanting building or house built on the Kahayan River is always oriented upstream or has a longitudinal position along the river.

\section{CONCLUSION}

The concept of Indigeneous knowledge system (IKS) is a concept promoted in the management of peat swamp rivers in a social cultural understanding with the approach of localy paradigm (local paradigm). The underlying reason is the closeness of life values from dependence on the resources and ecosystems that support people around peatlands. Within this framework, local communities are better positioned to monitor and respond to ecological feedback. In the sense that the Dayak community has information that is naturally increased and the mechanisms of local knowledge are active in responding to the surrounding ecological changes.

In the translation of the local knowledge system that is owned by the Dayak community, Dayaks can face all the difficulties and challenges of the peat environment and define themselves as mature individuals who are responsible for making the right decisions. Like the translation of IKS in attributes, historical buildings, equipment and tools crystallized in symbols - cultural symbols that are rich in art and values such as saka / handil and lanting houses.

\section{REFERENCE}

\section{Book}

Andasputra, Nico, Jhon Bamba \& Edi Petebang, 2001. Pelajaran Dari Masyarakat Dayak: Gerakan Sosial dan Resiliensi Ekologis di Kalimantan Barat. Kalimantan Barat : WWF- BSP dan Institut Dayakologi.

Boije, Honnie,2010. Analysis In Qualitative Research. London : Sage Publication.

Chatab,Nevizond,2007. Profil Budaya Organisasi, Bandung : Alfabeta

Cresswell,John.W.2010. Research Design : qualitative, quantitative and Mixed methods approaches, London: Sage publication.

Faure, Malcolm Munro \& Lesley Munro Faure, 1996. The Succes Culture: How to Build an Organization with vision and purpose, London: Pitman Publishing.

Saefullah,H.A.Djadja, 2011. Pemikiran Kontemporer Administrasi Publik ; Perspektif Manajemen Sumber Daya Manusia dalam Era Desentralisasi. Bandung: LP3AN FISIP UNPAD

Riwut, Tjilik, 2003. Kalimantan Membangun Alam dan Kebudayaan. Jogjakarta: NR Publishing.

\section{Journal}

Alawi, Adel Ismail.A., Wayla Yosif, Marzooqi \& Yasmeen Fraidon Mohammed, 2007. "Organizational Culture and Knowledge Sharing Critical Success Factors". Journal of Knowledge Management Vol. 11 No.2 : 22-42.

Weddel, Janine.R, Chris Shore, Gregory Feldman \& Stacy Lathrop,2005.

"Toward an anthropology of public policy". Journal of annals of the American Academy of Political and Social Science. Vol. 600. (Juli,2005) pp.30-51. 
Okrgwu,Anne Francis \& Joan P.Mencher, 2000.

"Anthropolgy of public policy: Shifting Terrains". Annual Review of Antropology Vol.29 (2000)pp. 107-124.

\section{Prosiding:}

Sihombing, R.Sally. 2016. Inovasi yang berwawasan lokal wisdom dalam meningkatkan pembangunan desa. Hal.219-229. Prosiding Seminar dan Lokakarya Nasional 2016 Indonesian Association for Public Administration Sumut - NAD.

\section{Thesis /Disertation:}

Bambang Hariyadi. 2008. Manajemen Pengelolaan Sungai secara tradisional alami di Serampas, Jambi. : Disertasi.Program Pascasarjana UI Jakarta .185 hal.

Sihombing, R.Sally. 2016. Karateristik Budaya Organisasi Balai Wilayah Sungai II Kalimantan dalam Pengelolaan Sungai Kahayan. Disertasi. Program Pascasarjana Universitas Padjadjaran. 250 hal.

Suciati. 2010 . Pengelolaan Wilayah Sungai Di Indonesia dalam Perspektif Otonomi Daerah. : Disertasi. Program Pascasarjana UGM Jogjakarta

Rani Sawitri. 2012. Strategi Pengelolaan Lingkungan pada Ekosistem Manggrove Disekitar Muara Sungai Bogowonto Kabupaten Kulon Progo. Disertasi. Program Pascasarjana UGM Jogjakarta

Robertus Chandrawijaya. 2012. Kolokium Hasil Penelitian dan Pengembangan Sumber Daya Air. Tinjauan Potensi Regime Sungai Kapuas Kalimantan Tengah.Balai Rawa, Bandung 2 - 3 Mei 2012.

Sangalang, Indrabakti, 2013. Keterikatan Pada Tempat Untuk Hunian Di Tepi Sungai Referensi Suku Dayak Ngaju di Palangka Raya. Disertasi.Program Pascasarjana ITS Surabaya:

\section{Internet:}

http://www.unpad.ac.id/2015/03/prof-dr-1-jan slikkerveer-kearifan-masyarakat-lokal-jangan-sampaipunah/

\section{Law}

Undang - Undang No.7 Tahun 2004 tentang sumber daya air.

\section{Report}

Main Synthesis Report . Masterplan for Rehabilitazion and Revitalization Of The Ex Mega Rice Project Area in Central Kalimantan. October 2008.Euroconsult Mott MacDonald and Deltares ,Delf Hedraulics in Association with DHV, Wageningen UR, Witteveen + Bos,PT MLD and PT INDEC. 